\title{
RUGALMAS GYÁRTÓRENDSZER HATÉKONYSÁGÁNAK NÖVELÉSE DOLGOZÓI KÉPESSÉGEK SZIMULÁCIÓJÁRA ALAPOZOTT TERMELÉSTERVEZÉSI MÓDSZERREL
}

\author{
Tóth Norbert \\ tudományos munkatárs \\ Bay Zoltán Nonprofit Kft. \\ 3519 Miskolc, Iglói út 2., e-mail: norbert.toth@bayzoltan.hu \\ Kulcsár Gyula \\ egyetemi docens, Miskolci Egyetem \\ Informatikai Intézet, Alkalmazott Informatikai Intézeti Tanszék \\ 3515 Miskolc, Miskolc-Egyetemváros, e-mail: iitkgy@uni-miskolc.hu
}

\begin{abstract}
Absztrakt
Az Ipar 4.0 és a különbözö digitalizációs megoldások egyre szélesebb körben való elterjedése mellett a termelési és logisztikai folyamatok müködésében továbbra is meghatározó szerepet játszik az emberi tényezö. Ezért olyan digitális modellek, számitási algoritmusok kidolgozása válik szükségessé, amelyek a termeléstervezés, a gyártási szekvenciák meghatározása során integráltan képesek figyelembe venni a dolgozók gyártási képességeit is. A feladat komplexitásából eredően a vizsgálatokra szimulációs modelleket alkalmaznak. Az ilyen modellekkel hatékonyan vizsgálhatók a dolgozói képességekkel kibövitett termelésütemezési rendszerek teljesitöképessége. Cikkünkben bemutatásra kerül egy általános szimulációs rendszermodell és egy termelésütemezést támogató új heurisztikus algoritmus. Szimulációs vizsgálattal igazoltuk, hogy a javasolt módszer javitja a vizsgált termelörendszer hatékonyságát az eröforrások kihasználtsága szempontjából.
\end{abstract}

Kulcsszavak: digitális modellek, szimuláció, termelésütemezés, dolgozói képességek

\begin{abstract}
In addition to the spread of Industry 4.0 and various digitization solutions, the human factor continues to play a key role in the operation of production and logistics processes. Therefore, development of digital models and calculation algorithms that are able to take into account the production capabilities of the employees in an integrated way during the production planning and the determination of the production sequences becomes necessary. Due to the complexity of the task, simulation models are often applied. Performance of production scheduling systems enhanced with employee capabilities can be effectively evaluated with such models. Our paper presents a general simulation system model and a new heuristic algorithm to support production scheduling. The simulation based investigation proved that the proposed method improves the efficiency of the studied production system in terms of resource utilization.
\end{abstract}

Keywords: digital models, simulation, production planning, production capabilities of the employees 


\section{Bevezetés}

A termelő vállalatok - multinacionális cégek, kis- és középvállalatok - közös jellemzője, hogy a menedzsment a vevői igények minél magasabb színvonalú kiszolgálását tüzik ki célul a megrendelések rövid átfutási idővel való teljesítése és megfelelő minőségi feltételek biztosítása mellett [1]. A vevői megrendelések nagy száma a készterméktípusok számának drasztikus növekedését eredményezi, amely hatással van a gyártórendszerek kialakítására, a termelési és logisztikai folyamatok müködtetésére.

A nagysorozatú gyártást felváltják a kis- és közepes sorozatok, valamint egyre fontosabbá válnak az egyedi igények gyártását támogató rendszerek, ahol az egydarabos anyagáramlás lesz a jellemző [2]. Ezen igények kielégítése csak és kizárólag a gyártó- és logisztikai rendszer nagyfokú rugalmassága és összehangolt müködése mellett valósítható meg, amelyet az Ipar 4.0 fejlesztési irányzat kínálta lehetőségek még inkább képesek támogatni az infokommunikációs, digitalizációs és virtualizációs technológiák széleskörü együttmüködésének segítségével [3]. A valós gyártórendszerek termelési és logisztikai folyamatainak digitális leképzése támogatja a szúkkeresztmetszetek feltárását [4], amelyek csökkentésére szimulációs vizsgálatok alkalmazhatók. A digitális modellben a valós folyamatok leképzése valósul meg egy olyan absztrakciós szinten, ahol lehetségessé válik a rendszer müködését jellemző mutatószámok kiértékelése és az azokat befolyásoló paraméter-értékek vizsgálata [5]. A digitális modelleken a rendszer bemenő paraméter-értékeinek változtatásával kísérletek végezhetők a valós folyamatok zavartalan müködésének biztosítása mellett.

A szimulációs vizsgálatok alkalmazásának jelentősége egyre jobban felértékelődik, hiszen egy-egy valós probléma megoldására készült általános modell számos paramétert tartalmaz, amely a kiértékelésen túl különböző müködtetési stratégiák vizsgálatára vagy a rendszer folyamatainak újratervezésére is felhasználható. A vizsgált rendszerek jellemzően diszkrét termelési és a hozzá kapcsolódó logisztikai folyamatokból állnak. E rendszerek digitális leképzéséhez speciális modellező szoftverek állnak rendelkezésre, amelyek széles objektumkészlettel támogatják a termelési, gyártási és logisztikai folyamatok modellezését.

Az egyik ilyen szoftver a Siemens cég Tecnomatix termékcsaládjának a digitális gyártást támogató és modellező Plant Simulation tervező szoftvere, amely egy általános diszkrét-eseményvezérelt szimulációs fejlesztőkörnyezet. Gazdag objektumkészletének segítségével a legkülönbözőbb termelési, gyártási és logisztikai rendszerek folyamatainak modellezésére és szimulációs vizsgálatára nyílik lehetőség [6], [7]. A SimTalk programozási nyelvvel saját algoritmusok, vezérlő eljárások, függvények készíthetők, amellyel a folyamatok valósághübb, részletesebb leképzését támogatja [8].

A legtöbb diszkrét gyártási folyamatok közös jellemzője, hogy a munkadarabokon előre definiált sorrendben gyártási-szerelési müveleteket (operációkat) kell végrehajtani bizonyos gépeken vagy munkahelyeken. Az egyik tipikus alapvető gyártási séma az úgynevezett „flow shop” (egyutas) modell, melyben a munkadarab-halmazokon (munkákon) azonos múveleteket, azonos sorrendben, azonos erőforrásokon kell végrehajtani. Ennek további alkategóriái lehetnek, például az előzéses és előzésmentes változatok, melyekben a munkák végrehajtási sorrendje erőforrásonként különbözö/vagy azonos lehet [9], [10], [11].

Egy másik tipikus séma a ,job shop” modell, melyben a különböző munkákon elvégzendő műveletek sorrendje eltérő lehet [12]. Mindkét típusú modell lehet ún. rugalmas (flexible) is, amennyiben egy operáció végrehajtásához nem csupán egy gép, hanem egy gépcsoport tartozik, akkor a gépválasztáshoz döntési feladat is párosul [13], [14], [15]. A feladatok komplexitásából adódik már kis gépszám mellett is, hogy optimális ütemterv készítése - polinomiális futási idő mellett - nem lehetséges, mivel 
a modellek túlnyomó többsége NP-nehéz problémaosztályba tartozik. Egzakt, számításigényes megoldás helyett előtérbe kerülnek az optimum-közeli megoldást adó gyors heurisztikus- és metaheurisztikus algoritmusok, keresőeljárások alkalmazása [16]. A valós gyártórendszerek termelésütemezésének támogatására olyan komplex modellek kidolgozása szükséges, amelyek a termelési folyamatban jelentkező paraméterek mellett a logisztikai folyamatokhoz kapcsolódó paramétereket, befolyásoló tényezőket, sztochasztikus hatásokat is képesek figyelembe venni.

A cikkben összefoglalt kutatómunkánkat egy különösen rugalmas szerelőrendszer valós problémája indukálta. A következő fejezetekben bemutatásra kerül egy szimulációs modell és egy új termelésütemezési heurisztikus algoritmus, amellyel a vizsgált rendszer minél magasabb teljesítményét eredményező napi termelési tervek elkészíthetők. A rendszer specialitását az emberi erőforrások (személyek) egyéni szerelési képességeit is magába foglaló termelési modell adja, amely tovább növeli a rendszer paramétereit és komplexitását. A kiterjesztett döntéshozatali algoritmus hatékonyságát szimulációs futási eredményekkel támasztjuk alá.

\section{Probléma definiálása}

\subsection{Operációk és munkahelyek}

Napjainkban a vállalatok versenyképességének fokozása elsődleges prioritású szerepet játszik a vevői megrendelések határidőre történő teljesítése a produktív termelési folyamatok teljesítményének maximalizálása a non-produktív logisztikai folyamatok minimalizálása, a veszteségek csökkentése mellett.

A gyártási folyamatokban egyik veszteségként jelentkezik a terméktípusok közötti váltáshoz kapcsolódó átállítási idő, amelynek csökkentésére az optimum-közeli gyártási szekvencia szerinti gyártás adhat megoldást. A vevői igények megváltozása következtében olyan gyártási struktúrák kerülnek előtérbe, ahol a termelési folyamatban egyidejüleg különböző típusú termékek gyártása folyik és az operációk sorrendje kötött, nem felcserélhető, de terméktípusonként akár számosságában is eltérő lehet. Az egyes operációk olyan géphez vagy az ekvivalens gépekből álló gépcsoporthoz kötöttek, ahol a szükséges müveletek elvégezhetők. Az Ipar 4.0 technológiák alkalmazásának eredményeképpen az egyes berendezések autonóm módon képesek müködni, hálózatba kötve kommunikálnak egymással.

Mivel a gépek és a munkadarabok is azonosítottak, a gépek képesek az aktuális operációjuk befejezését követően jelzést küldeni az aktuális munkadarab soron következő operációját végző gép számára, annak érdekében, hogy a két gép közötti szállítási idő alatt lehetősége legyen a következő gépnek felkészülnie az új munkadarab fogadására, csökkentve ezzel az átállítási időt. A rendszerben egyidőben jelenlevő különböző terméktípusok miatt bonyolult anyagáramlási relációk keletkeznek. Az 1. ábra példaként illusztrálja a ,job shop" problémát egy irányított gráf formájában 4 termékre és 5 gépre vonatkozóan.

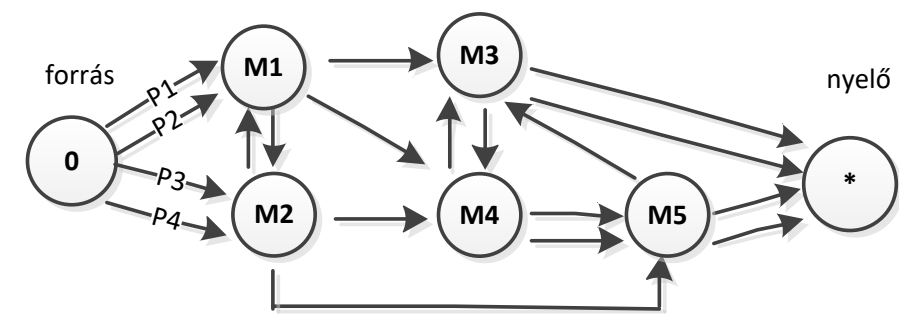

1. ábra. A vizsgált ,job shop” termelési folyamat mintamodellje. 
Az 1. táblázat a terméktípusonkénti operációk sorrendjét mutatja.

1. táblázat. Terméktípusonkénti müveletetek sorrendje

\begin{tabular}{|c|c|c|c|c|c|}
\hline & $\mathrm{M} 1$ & $\mathrm{M} 2$ & $\mathrm{M} 3$ & $\mathrm{M} 4$ & $\mathrm{M} 5$ \\
\hline $\mathrm{P} 1$ & $\mathrm{O}_{1} / \mathrm{t}_{1}$ & $\mathrm{O}_{2} / \mathrm{t}_{2}$ & & $\mathrm{O}_{3} / \mathrm{t}_{3}$ & $\mathrm{O}_{4} / \mathrm{t}_{4}$ \\
\hline $\mathrm{P} 2$ & $\mathrm{O}_{1} / \mathrm{t}_{5}$ & $\mathrm{O}_{3} / \mathrm{t}_{6}$ & & $\mathrm{O}_{2} / \mathrm{t}_{7}$ & \\
\hline $\mathrm{P} 3$ & $\mathrm{O}_{2} / \mathrm{t}_{7}$ & $\mathrm{O}_{1} / \mathrm{t}_{8}$ & $\mathrm{O}_{3} / \mathrm{t}_{8}$ & & \\
\hline $\mathrm{P} 4$ & & $\mathrm{O}_{1} / \mathrm{t}_{8}$ & $\mathrm{O}_{3} / \mathrm{t}_{9}$ & $\mathrm{O}_{4} / \mathrm{t}_{10}$ & $\mathrm{O}_{2} / \mathrm{t}_{11} \mathrm{O}_{4} / \mathrm{t}_{12}$ \\
\hline
\end{tabular}

Minden egyes operációhoz $\left(\mathrm{O}_{\mathrm{i}}\right)$ tartozik egy feldolgozási idő $\left(\mathrm{t}_{\mathrm{j}}\right)$, amely ahhoz szükséges, hogy az adott terméktípus adott mủvelete az adott gépen elvégezhetö legyen.

\subsection{Humán erőforrások}

Az előző ábrán (1. ábra) számos anyagáramlási reláció létezik az egyes gépek vonatkozásában. Az anyagmozgatás automatizált módon történő megvalósításának költséges kialakítása helyett ezt a feladatot dolgozók látják el. A dolgozók a rendszer bemenő tárolójából (forrás) választják ki a soron következő munkadarabot, majd az adott terméktípusnak megfelelő műveleti sorrend szerint mozgatják a munkadarabot az egyes szerelő állomások (gépek) között. Az állomásokon elvégzik a szükséges operációkat. Egy munkahelyen egy időben egy dolgozó hajthat végre mủveletet. Amennyiben egy munkaállomás foglalt a dolgozó várakozik, amíg az fel nem szabadul. Az utolsó mủvelet elvégzése után az összeszerelt termék a késztermék tárolóba kerül (nyelö). Ezt követően a ciklus kezdődik elölről. Így a vizsgált rendszerben a dolgozók valósítják meg az egydarabos anyagáramlást. A munkaállomásokon a szerelési folyamat nem szakítható meg. A dolgozók csak és kizárólag a termék készterméktárolóban való elhelyezése után (a megkezdett ciklus végén) dönthetnek a szünetek kivételéröl.

A humánerőforrás alkalmazásának számos előnye mellett a negatív hatások is megjelennek a termelési folyamat produktivitására nézve, mivel a müszakszintü/napi/heti termelési tervek teljesülése a rendszerben lévő sztochasztikus hatásoktól függ, amelyek az emberek egyediségéből fakadnak leginkább. Az emberek közötti különbségek legjobban az egyes operációkhoz tartozó normaidők betartása alapján mérhetők, hiszen minden operációhoz tartozik egy előre definiált normaidő, amely a termelési tervek készítésének alapjául szolgál.

Ezekből tervekből származnak a müszakszintű termelési tervek - jellemzően egy adott időszakra nézve egyenletesen elosztva a müszakok között. Bár a dolgozóktól elvárás a normaidő betartása, mégis bizonyos különbségek fedezhetők fel, amely a dolgozó gyártási-szerelési képességeiböl fakad. Míg egy új betanuló dolgozó nem képes a normaidők maximális betartására, addig a gyakorlottabbak normaidő alatt is képesek elvégezni a müveleteket. Az éjszakai és nappali müszakokban dolgozók között szintén különbségek lehetnek. A dogozói képességet tehát egy adott müvelet elvégzésének normaidejéhez (átlagidejéhez) viszonyítva százalékos formában értelmezhetjük.

A vizsgált termelési folyamat komplexitása tovább nőtt a dolgozói képességek figyelembe vételével, amely a termeléstervezési, ütemezési modellekre és algoritmusokra is kihat. A rendszer bonyolultsága teszi indokolttá a szimulációs modellek és módszerek alkalmazását, amellyel a rendszer termelékenységére, hatékonyságára vonatkozó mutatószámok kiértékelhetők a különböző termelési tervek és dolgozói képességek függvényében. 


\section{A vizsgált rendszer digitális modellje}

\subsection{A szimulációs modell legfontosabb elemei}

A bemutatott termelő rendszer vizsgálatát egy digitális modell kidolgozása előzte meg. A modellben valós termelési és logisztikai folyamatok kerültek leképzésre az alábbi módon:

- Termelö berendezések (munkaállomások, gépek) modellezése: A termelési folyamatban 50 $\mathrm{db}$ termelő berendezés található (A1-A50), elhelyezkedésük rögzített. A termelö berendezés és a dolgozó együttmüködése eredményezi a munkadarabon a gyártási folyamat elemi operációját, melynek során a munkadarab valamely lényeges tulajdonsága megváltozik. A tulajdonságváltozások irányított sorozata alkotja a gyártási folyamatot, amely a munkadarabot a kiindulási állapotból a kész állapotba transzformálja. A müvelet (operáció) legfontosabb paramétere a dolgozói képességektől függő feldolgozási idő, amely az adott termék adott operációjának az adott munkaállomáson (gépen) történő végrehajtásának normaidejéből származtatható (1).

$$
t=t_{p_{i k}}^{A_{j}}+t_{p_{i k}}^{A_{j}}\left(1-B_{p_{i k}}^{\text {Operator }} / 100\right)
$$

ahol:

- $A_{j}:$ a j. gép.

- $\quad p_{i k}: i$. terméktípus $k$. operációja.

- $t_{p_{i k}}^{A_{j}}: i$. terméktípus $k$. operációjának normaideje az $A_{j}$ gépen.

- Operator $r_{l}: l$ operátor.

- $B$ : az operátor gyártási képessége.

- $B_{p_{i k}}^{\text {Operator }}$ : százalékos formában adja meg, hogy az $i$. terméktípus $k$. operációjának normaidejét mekkora mértékben képes betartani az $l$. operátor.

- Ha az operátor $100 \%$-osan képes az adott müvelethez tartozó normaidőt tartani, akkor az operáció müveleti ideje megegyezik a normaidővel.

- Ha az operátor $100 \%$-osnál kisebb mértékben képes az adott müvelet normaidejének betartására, akkor a normaidő növekszik, hiszen lassabban dolgozik az operátor, így az operáció müveleti ideje nagyobb lesz a normaidőnél.

- Ha az operátor $100 \%$-osnál nagyobb mértékben képes az adott müvelet normaidejének betartására, akkor a normaidő csökken, hiszen gyorsabba dolgozik, így az operáció müveleti ideje kisebb lesz a normaidőtől.

- Dolgozók modellezése: A dolgozók a munkaállomások (gépek) között előre definiált útvonalon, megadott átlagsebességgel közlekednek. A munkadarabot a „Start” elnevezésü bemeneti tároló objektumról választja ki a dolgozó, majd a terméktípushoz kapcsolódó müveleti sorrend szerint egyesével keresi fel a munkaállomásokat. Az utolsó mủveletet követően az „End” elnevezésủ késztermék tároló objektumon elhelyezi a készterméket. A dolgozók előre megadott hosszúságú szünetekkel rendelkeznek. Ezeket a szüneteket saját döntésük alapján használhatják fel. A szüneteket csak a késztermék leadása után lehet elkezdeni, megkezdett gyártási müveletsor közben nem. Egy időben több operátor is dolgozik, így a közösen használt (osztott hozzáférésü) munkaállomások elött várakozó sorok alakulhatnak ki, mivel egy 
munkaállomáson egyidejüleg csak egyetlen operátor dolgozhat. Az operátor mindaddig az állomásnál marad, míg az aktuális operációt el nem végezte a képességeinek függvényében. Az operációk nem megszakítható folyamatok. Léteznek azonos tulajdonságokkal rendelkező gépek, amelyek ekvivalens gépekből álló gépcsoportot alkotnak (így bizonyos mủveletek elvégzésére párhuzamos gépek állnak rendelkezésre). A modellben 23 operátor került implementálásra (Operator1, .., Operator23), különböző (nagyon, közepesen, kevésbé hatékony) képességekkel.

- Termékek modellezése: A modellben 15 termékcsalád és 100 terméktípus létezik. A müveleti sorrendet a termékcsaládokra értelmezzük. A terméktípusok a termékcsaládok egyes specializálódásai, így az ezeken végrehajtott operációk száma és sorrendje megegyezik a termékcsaládéval, azonban az operációk normaideje típusonként eltérö lehet.

- „Start” objektum (forrás): Bemeneti tárolóként funkcionál. A gyártásra váró munkadarabok tárolja, amelyek közül választ egyet az oda érkező operátor.

- „End” objektum (nyelö): A késztermékek tárolását megvalósító objektum. A készre gyártott terméket az operátorok itt helyezik el.

A termelő rendszer Plant Simulation modelljét a 2. ábra mutatja be, a termelő berendezésekkel, a dolgozókkal és az aktuálisan gyártott terméktípusokkal együtt. A dolgozók dedikált útvonalon közlekednek. Útvonal ott jelenik meg, ahol két munkaállomás anyagáramlási relációban áll egymással.

Illusztratív példaként két terméktípus Sankey diagramja is látható, melyek vastagsága szemlélteti a terméktípusokból legyártott volumen nagyságát, továbbá megjelenítik a terméktípus technológiai folyamatához tartozó munkahelyeket. A modell müködéséhez, a rendszerben zajló időbeli folyamatok vizsgálatához nagymennyiségü alapadat szükséges, amely strukturált formában külső adatbázisban helyezkedik el. Az alapadatok a modell alapobjektumainak tulajdonságai (termékek, gépek, dolgozók) mellett a köztük lévő anyagáramlási relációkat, logikai kapcsolatokat is tartalmazzák. A modell implementálása során a korábban kidolgozott modellépítés koncepcióját követve [4] lehetséges a modell struktúrájának gyors adaptálása az alapadatok módosításával. Az módosított alapadatoknak megfelelöen a modell struktúrája automatikusan megváltozik. Munkahelyek, dolgozók, termékek jönnek létre vagy szünnek meg, a modell objektumainak tulajdonságai, adattagjai dinamikusan frissülnek.

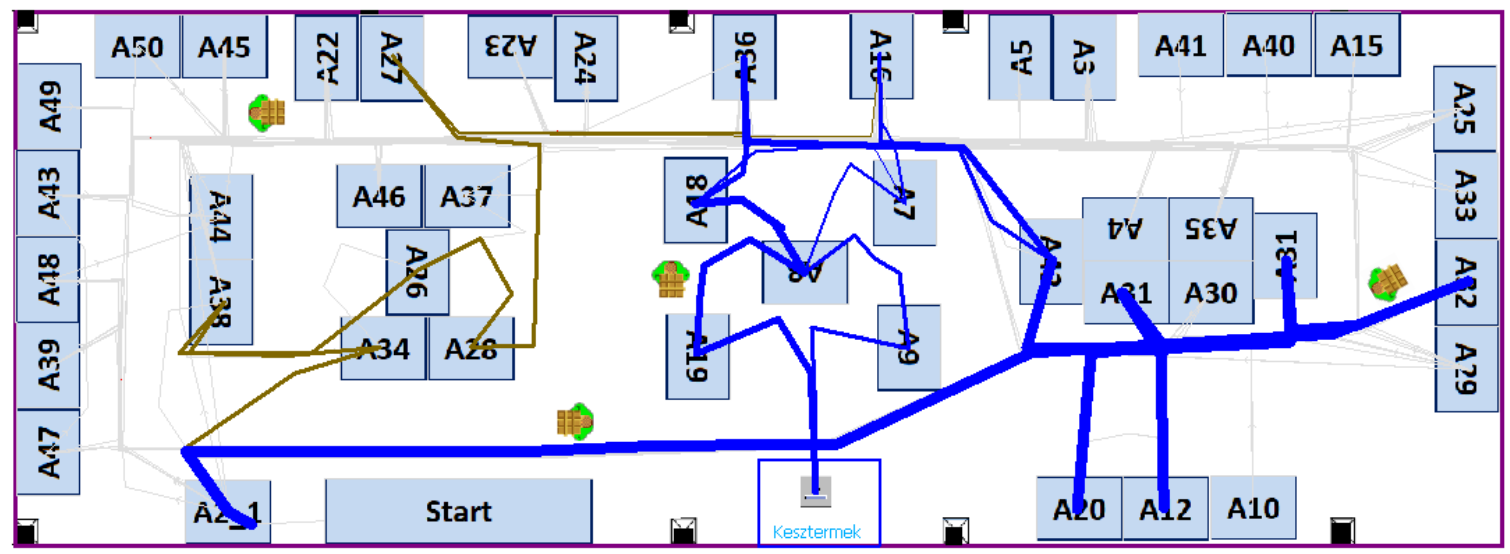

2. ábra. Szimulációs modell.

A vázolt dinamikus viselkedésü digitális modell müködéséhez az alábbi konzisztens adatokat, adatstruktúrákat alkalmaztuk: 
- Dolgozók listája, a dolgozók egyedi müszakrendje, müszaktípushoz rendelése.

- Müszakrend, müszakbeosztás: 8 vagy 12 órás müszakok ciklikus változása napi bontásban. A müszakokban a különböző képességü dolgozók vegyesen állnak rendelkezése.

- Termékcsaládok, terméktípusok listája.

- Termékcsaládok gyártási müveleteinek sorrendje, a múveletek munkaállomásokhoz való hozzárendelése, ahol az adott operáció elvégezhető.

- Terméktípusok operációinak normaideje, amely az elvárt müveleti időt reprezentálja.

- Terméktípusok operációnkénti normaidejének és az operátorok képességeinek mátrixa, ahol a mátrix egy eleme megmutatja, hogy az adott operátor az adott operáció müveleti idejét (normaidejét) mekkora százalékban képes betartani.

- Operátorok átlagos képességmátrixa az egyes termékcsaládok tekintetében: a mátrix egy eleme megadja, hogy az adott operátor az adott termékcsaládhoz tartozó bármely operáció normaidejét mekkora százalékban képes betartani.

- Termelési tervek listája:

- A vizsgált időszakban legyártandó darabszám terméktípusonként.

- A vizsgált időszakban müszakonként legyártandó darabszám terméktípusonként.

A termelési folyamat hatékonyságát, a termelési terv teljesülését nagyban befolyásolja a vizsgált időszakban a különböző müszaktípusok sorrendje és darabszáma, illetve az egyes müszaktípusokhoz rendelt dolgozók és gyártási képességeik.

\subsection{Szimulációs vizsgálat}

A szimulációs vizsgálatunk célja a rendszer hatékonyságának és teljesítőképességének elemzése változó körülmények között. A vizsgálat első lépéseként be kell állítani a modell bemenő paramétereinek aktuális értékét. Jelenleg két fő bemenő paraméter-halmaz adható meg:

- A vizsgált időszak, amely definiálja a müszakok sorrendjét, számosságát, az egyes müszaktípusokban dolgozó operátorokat és képességeiket.

- A vizsgált időszakra vonatkozó termelési tervet kétféle módon:

- A legyártandó mennyiség a teljes vizsgált időszakra vonatkozik, amelyből automatikus módon a müszakszámok függvényében egyenletesen elosztva készülnek a müszakonkénti termelési tervek.

- A legyártandó mennyiség direkt módon müszakonként is megadható.

A szimulációs vizsgálat eredményei tekintetében különböző kimutatások készíthetők a rendszer teljesítményére, a dolgozók kihasználtságára, a gyártott darabszámra vonatkoztatva. Az egyik legfontosabb szempont a termelési terv teljesülésének mértéke, ezért az egyik fő mutatószám a gyártott darabszám. A másik mutatószám pedig a rendszer időbeli szabad kapacitása. E két mutatószám egymáshoz való viszonyából az alábbi következtetések vonhatók le:

1. Amennyiben a termelési terv nem teljesül, azaz léteznek le nem gyártott darabok és a rendszer időbeli szabad kapacitása jelentős, akkor az arra utal, hogy bizonyos müszakokban nem minden tétel került legyártásra a dolgozók gyártási képességei vagy nem megfelelő irányítási döntések miatt.

2. Amennyiben a termelési terv nem teljesül, azaz léteznek le nem gyártott darabok és a rendszernek nincs jelentős időbeli szabad kapacitása, akkor az túltervezett termelési tervre utal, azaz a tervezett mennyiség nem gyártható le az adott időszakban. 
3. Amennyiben a termelési terv teljesül és a rendszernek jelentős időbeli szabad kapacitása van, akkor az alultervezett termelési tervre utal, a dolgozók szabad gyártókapacitással rendelkeznek, a rendszerben további termékek gyárthatók.

4. Amennyiben a termelési terv teljesül és a rendszernek nincs jelentős időbeli szabad kapacitása, akkor az a termelési terv valószínüleg maximálisan kihasználja a rendszer erőforrásait és elosztása is megfelelő az egyes müszakok között.

A rendszer teljesítményét, a gyártott darabszámokat nem csupán a termelési terv múszakonkénti elosztása befolyásolja, hanem a dolgozók müködését meghatározó irányítási, döntési stratégia is. A modellben két olyan esemény került implementálásra, amely a dolgozók tevékenységét és a gyártórendszer teljesítményét befolyásolja:

1. A gyártandó terméktípusok és az operátorok összerendelése a „Start” objektumnál, ahol az adott múszakban gyártandó terméktípusok egy várakozó sort alkotnak. A várakozó munkadarabok sorából választ egyet az operátor. Az operátor alapértelmezett kiválasztási stratégiája, hogy a várakozó sorból azt a legkisebb pozíciószámú elemet választja ki, amelyiket le tud gyártani. Másképpen fogalmazva, az operátor az általa gyártható elemek közül a legelsőt választja. A dolgozó képességei miatt léteznek olyan termékcsaládok, amelyek gyártására egyáltalán nem képes. Ez egy egyszerü összerendelés, de számos hatása lehet a termelési folyamatra nézve. Igen érzékeny a várakozó sorban álló elemek sorrendjére. Ha az egymás mögött álló munkák azonos termékcsaládba tartoznak és ezek gyártására a dolgozók képesek, akkor a dolgozók ugyanazt a technológiai utat járják be, ugyanazon munkaállomásokat keresik fel sorban egymás után. A munkaállomások előtt pedig várakozó sorok alakulhatnak ki, amelyek a termékek gyártásának átfutási idejét megnövelik, rontva ezzel a rendszer teljesítőképességét.

2. Választás ekvivalens gépek között. Bizonyos operációk (pl. befejező müveletek) esetében egynél több gép áll rendelkezésre azonos típusú operációk elvégzésére. Ebben az esetben a dolgozó döntési stratégiája a lehetséges gépekre számított büntetőfüggvény kiértékelésén alapul, amely figyelembe veszi a gép (munkahely) foglaltságát és a gyártott darabszámot. Azt a gépet választja, amelyiknél a függvény értéke minimális.

A szimulációs vizsgálataink megerősítették azt a kezdeti feltételezésünket, hogy a vizsgált gyártórendszer produktivitása és az erőforrások megfelelő mértékü kihasználtsága a sok befolyásoló paraméter és döntési stratégia mellett a munkák várakozási sorban adott szekvenciájától is függ, a dolgozók és a gyártandó munkadarabok összerendelése miatt.

\subsection{Szimulációs eredmények}

A szimulációs modell alkalmas a termelési terv teljesülésének vizsgálatára. A vizsgálat 7 napra, 14 darab 12 órás müszakra terjed ki. A dolgozók müszakokhoz rendelése és képességeik előre definiálva voltak. A modell legfontosabb bemenő paraméterei az alábbiak:

- A dolgozói képességek:

- elméleti operátorképességek: az operátorok gyártási képességeinek figyelmen kívül hagyásakor minden operátor mindegyik terméktípust 100\%-osan, a normaidőnek megfelelően képes gyártani.

- átlagos operátor képességek: a mủveleti idő az elvárt normaidő és a dolgozó átlagos képességéből származtatható.

- A termelési terv a vizsgált időszakra (2. táblázat): 


\begin{tabular}{|c|c|}
\hline Terméktípus [ID] & Mennyiség [db] \\
\hline$\_060127$ & 136 \\
\hline$\_060159$ & 238 \\
\hline$\_160700$ & 963 \\
\hline$\_06016 \mathrm{~A}$ & 123 \\
\hline$\_060125$ & 749 \\
\hline$\_060162$ & 82 \\
\hline$\_06015 \mathrm{~A}$ & 73 \\
\hline _06016B 0 & 352 \\
\hline
\end{tabular}

- A vizsgálat időintervalluma, müszakok sorrendje. A termelési terv a müszakok számának megfelelően egyenletesen megoszlik a müszakok között (kerekítéssel).

A rendszer két kitözött teljesítménymutatója:

- a gyártott darabszám,

- a rendszer időbeli szabad kapacitása.

A futási eredményeket az alábbi 3. táblázat foglalja össze a dolgozói képességek két vizsgált esetének szempontjából.

3. táblázat. Futási eredmények összehasonlitása

\begin{tabular}{|c|c|c|}
\hline & Elméleti operátorképességekkel & Átlagos operátorképességekkel \\
\hline Tervezett mennyiség [db] & 2716 & 2716 \\
\hline Gyártott mennyiség [db] & 2663 & 2632 \\
\hline Szabad kapacitás [perc] & 960 & 492 \\
\hline
\end{tabular}

A fenti táblázatból látható, hogy a gyártott darabszám még akkor is elmarad a tervezettől, amikor a dolgozók a maximális elméleti gyártási teljesítménnyel végzik a feladatokat. Az átlagos képességekkel futtatott szimulációban a gyártott mennyiség csökken, mivel a dolgozók nem képesek a normaidő alatt elvégezni az operációkat. Emiatt a termékek átfutási ideje megnő. A müszakonkénti gyártott mennyiségeket a 3. ábra mutatja be.

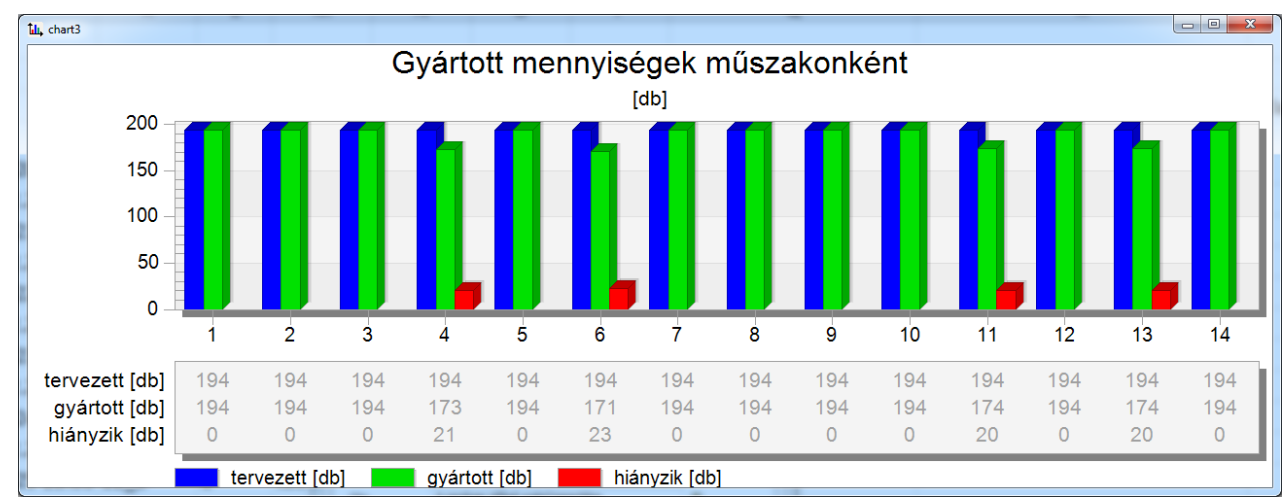

3. ábra. Gyártott mennyiségek megoszlása müszakonként. 
Mindkét esetben a rendszernek időbeli tartalékai vannak. Bizonyos esetekben a müszakonként tervezett termelési terv a müszak vége előtt teljesült. Az operátorok pedig várakoznak a müszak végéig.

Egy müszak időtartaléka alatt azt a fennmaradó időmennyiséget (időbeli szabad kapacitást) értjük, amely a müszak hasznos időalapjából és a müszakonkénti termelési terv teljesítéséhez szükséges idő különbségéből adódik. A rendszer időbeli szabad kapacitások elemzéséből (4. ábra) látszik, hogy bizonyos müszakok $(4,6,11,13)$ túlterheltek, a dolgozók nem képesek a müszakszintü termelési terv teljesítésére.

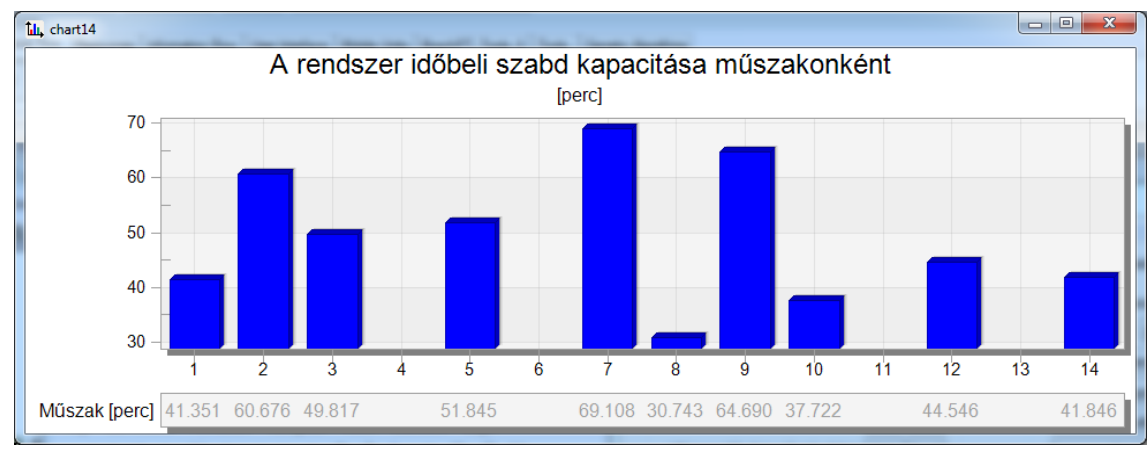

4. ábra. Időbeli szabad kapacitás megoszlása müszakonként.

\section{A saját fejlesztésü termelési terv optimalizáló (PPO) modul heurisztikus módszere}

A 3. ábra és 4. ábra alapján a gyártott darabszám növeléséhez implementálásra került a Plant Simulation környezetben egy - saját fejlesztésü - termelési terv optimalizáló modul (PPO), amely a termelési terv müszakonkénti egyenletes elosztásából kiindulva a legyártásra nem került termékeket olyan müszakokhoz rendeli, amelyek rendelkeznek időbeli szabad kapacitással és a dolgozók képesek a többlet feladatok teljesítésére.

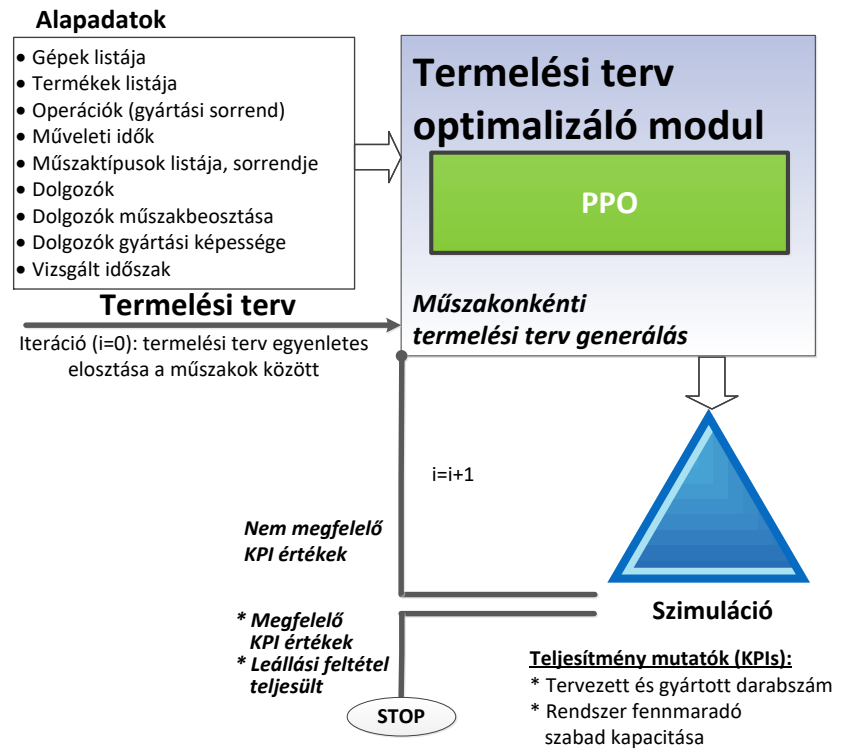

5. ábra. PPO modul iteratív keresö algoritmusának sematikus ábrája. 
A PPO (5. ábra) célja, hogy az egyenletes elosztású müszakonkénti termelési tervek módosításával javulást érjen el a rendszer teljesítménymutatóiban a dolgozói képességek figyelembevételével. Az előkészítő (0. iterációs) lépésben a modul a megadott termelési tervet egyenletesen elosztja a müszakok között, majd lefuttatja a szimulációt és kiértékeli a mutatószámokat. Amennyiben vannak le nem gyártott termékek, azokat az első olyan müszakhoz rendeli hozzá, ahol időbeli szabad kapacitás van és a dolgozók által is gyárthatók.

A módosított müszakonkénti termelési tervekkel ismét lefut a szimulációs vizsgálat és kiértékelődnek a teljesítménymutatók. Ez az iteratív folyamat mindaddig ismétlődik, amíg vannak le nem gyártott termékek és van szabad időbeli kapacitás a rendszerben vagy az iterációk száma el nem érte az elöre beállított maximális értéket. Az iterációs javító algoritmus már kis iterációs szám mellett is képes javulást elérni a rendszer teljesítménymutatóiban (6. ábra). A gyártott darabszám nőtt 2632-ről 2703-ra, amely a rendszer hasznos időalapjának jobb kihasználására utal. Ezt mutatja a rendszer időbeli szabad kapacitásának 492 percről 272 percre való csökkenése.

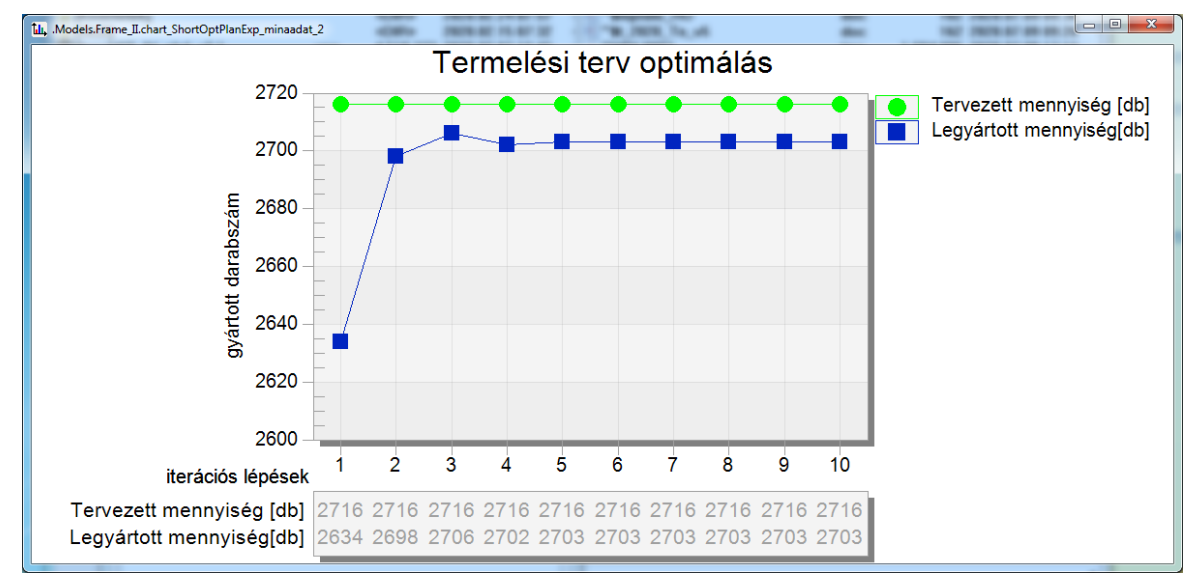

6. ábra. PPO modul iterációs lépései.

Az iteratív javító algoritmus eredménye egy müszakonkénti termelési terv, amelyet az alábbi 4. táblázat mutat be.

4. táblázat. Müszakonként gyártott darabszámok

\begin{tabular}{|c|c|c|c|c|c|c|c|c|c|c|c|c|c|c|}
\hline $\begin{array}{l}\text { Müszaktípusok } \\
\text { Terméktípus }\end{array}$ & 1.A & 2.B & 3.D & 4.C & 5.D & 6.C & 7.B & $8 . \mathrm{A}$ & 9.B & 10.A & 11.C & 12.D & 13.C & 14.I \\
\hline 060127 & 10 & 10 & 10 & 9 & 11 & 9 & 11 & 10 & 10 & 10 & 9 & 11 & 9 & 11 \\
\hline 060159 & 17 & 17 & 17 & 15 & 18 & 15 & 19 & 18 & 17 & 17 & 15 & 19 & 15 & 19 \\
\hline-160700 & 68 & 68 & 68 & 61 & 73 & 60 & 74 & 72 & 68 & 68 & 61 & 75 & 61 & 75 \\
\hline \begin{tabular}{|l|l}
$06016 \mathrm{~A}$ \\
\end{tabular} & 9 & 9 & 9 & 8 & 10 & 8 & 10 & 9 & 9 & 9 & 8 & 10 & 8 & 10 \\
\hline - 060125 & 53 & 53 & 53 & 46 & 57 & 46 & 58 & 58 & 53 & 53 & 48 & 58 & 48 & 58 \\
\hline 06016 & 6 & 6 & 6 & 6 & - & 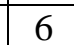 & 6 & 6 & 6 & 6 & 6 & 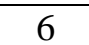 & 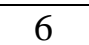 & 6 \\
\hline P0601 & 6 & 6 & 6 & 5 & 1 & 5 & 7 & 6 & 6 & 6 & J & l & 5 & 7 \\
\hline _0601 & 25 & 25 & 25 & 22 & 28 & 22 & 28 & 25 & 25 & 25 & 22 & 28 & 22 & 28 \\
\hline Egyenlete & 194 & 194 & 194 & 194 & 194 & 194 & 194 & 194 & 194 & 194 & 194 & 194 & 194 & 194 \\
\hline PO modullal & 194 & 194 & 194 & 172 & 210 & 171 & 213 & 204 & 194 & 194 & 174 & 214 & 174 & 214 \\
\hline
\end{tabular}


Az implementált heurisztikus algoritmus bizonyos müszakoknál csökkentette a gyártandó mennyiséget, míg más müszakoknál növelte azt. A „C típusú” müszakban dolgozók szük keresztmetszetként jelentek meg a rendszerben. Alacsony gyártási képességeik a müszak termelékenységét rontották.

\section{5. Összefoglalás és továbbfejlesztési irányok}

Cikkünkben bemutatásra került egy speciális gyártórendszer, ahol a humán erőforrás, a dolgozók gyártási hatékonysága, képessége kulcsfontosságú szerepet játszik a termelőrendszertől elvárható maximális produktivitásban, mivel az emberek egyénisége a gyártási folyamatra is kihat. Általánosságban is elmondható, hogy a termelési, gyártási feladatok szervezésében, a termeléstervezési és ütemezési modellekben integráltan meg kell jelennie az emberi faktornak annak érdekében, hogy a rendszer hatékonyságnövelésére tett változtatások a kívánt hatást érjék el. Ennek vizsgálatára kidolgozásra került egy digitális szimulációs modell, amely alkalmas az emberi tényező termelési folyamatra gyakorolt hatását figyelembevételére egy új heurisztikus algoritmus műszakonkénti termelési terv optimalizálása révén növelni a rendszer teljesítőképességét.

A munkák és a dolgozók összerendelésének más stratégiájával, a gyártási szekvencia optimalizálásával további javulás prognosztizálható, amennyiben a dolgozó mindig törekszik a gyártási képességének legmegfelelőbb munka kiválasztására oly módon, hogy figyelembe veszi a már gyártásban lévő terméktípusokat a munkaállomások előtti várakozási idő csökkentésének érdekében. Ez, a rendszerben aktuálisan gyártott munkák terméktípusainak maximális heterogenitásával biztosítható. Emellett tekintettel van a többi dolgozó gyártási képességére, azaz amíg nem muszáj, nem választ olyan munkát, amelyet csak kevesen tudnak - akár kisebb hatékonysággal is - gyártani, biztosítva ezzel a dolgozók folyamatos munkáját és a gyártott darabszámok növekedését.

Egy kvázi-optimális müszakszintü gyártási szekvencia meghatározásához további számos szempont kell figyelembe venni, amelyhez egy többcélú prioritás alapú termeléstervező eljárás kidolgozása válik szükségessé, amelyet a jelenleg alkalmazott szimulációs modell továbbfejlesztésével kívánunk elérni a továbbiakban.

\section{Irodalom}

[1] Szakál, F., Józsa, L: A 21. század fogyasztója, avagy mi a fontos a fogyasztónak a modern világban, "Kulturális gazdaság" Kautz Gyula Emlékkonferencia elektronikus formában megjelenő kötete, Széchenyi István Egyetem, Győr, 2019, ISBN 978-615-5837-34-0.

[2] Tóth, N., Ladányi, R., Garamvölgyi, E.: Elaborating Industry 4.0 compatible DSS for enhancing production system effectiveness, IOP Conf. Ser.: Mater. Sci. Eng. 2018, 448:012040, Kecskemét, Hungary, 2018, https://10.1088/1757-899X/448/1/012040

[3] Russmann, M., Lorenz, P., Gerbert, P., Waldner, M., Jastuss, J., Hengel, P., Harnisch, M.: Industry 4.0: the future of productivity and growth in manufacturing industries, The Boston Consulting Group report, 2015.

[4] Tóth, N. Termelési folyamatok intenzifikálását célzó új módszer bemutatása az Ipar 4.0 lehetöségei alapján, Müszaki Tudomány az Észak-kelet Magyarországi Régióban, Konferencia Kiadvány, Debrecen, 2019, pp. 396-399, ISBN978-963-7064-38-8.

[5] VDI-Richtlinie 3633 Blatt 1: Simulation von Logistik-, Materialfluss- und Produktionssystemen-Grundlagen, Düsseldorf, VDI-Verlag, 1993. 
[6] Siderska, J.: Application of Tecnomatix Plant Simulation for modeling production and logistics processes. Business, Management and Education 2016, 14(1):64-73, https://doi.org/10.3846/bme.2016.316

[7] Tamás, P., Illés, B., Tollár, S.: Simulation Of A Flexible Manufacturing System, Advanced Logistic Systems 2012, 6(1):25-32.

[8] SIEMENS AG: Tecnomatix Plant Simulation Help, 2017.

[9] Kulcsár, Gy., Erdélyi, F.: A New Approach to Solve Multi-Objective Scheduling and Rescheduling Tasks, International Journal of Computational Intelligence Research 2007, 3(4):343-351, https://doi.org/10.5019/j.ijcir.2007.115

[10] Kulcsár, Gy.: Ütemezési modell és heurisztikus módszerek az igény szerinti tömeg-gyártás finomprogramozásának támogatására, Doktori $(\mathrm{PhD})$ értekezés, Miskolci Egyetem, MiskolcEgyetemváros, 2007.

[11] Kulcsárné, F. M.: Kiterjesztett modellek és módszerek eröforrás-korlátos termelésütemezési feladatok megoldására, Doktori (PhD) értekezés, Miskolci Egyetem, Miskolc-Egyetemváros, 2017.

[12] Kulcsár, Gy., Kulcsárné, F. M.: Kiterjesztett termelésprogramozási modell eröforrás-korlátos ütemezési feladatok megoldására, Multidiszciplináris tudományok 2014, 4(1):19-30.

[13] Botta-Genoulaz, V.: Hybrid flow shop scheduling with precedence constraints and time lags to minimize maximum lateness. International Journal of Production Economics 2000, 64:101-111, https://doi.org/10.1016/S0925-5273(99)00048-1

[14] Low, C.: Simulated annealing heuristic for flow shop scheduling problems with unrelated parallel machines, Computers and Operations Research 2005, 32:2013-2025, https://doi.org/10.1016/j.cor.2004.01.003

[15] Demir, Y., İşleyen, S. K.:Evaluation of mathematical models for flexible job-shop scheduling problems, Applied Mathematical Modelling 2013, 37(3):977-988, https://doi.org/10.1016/j.apm.2012.03.020

[16] Fogarasi; G., Tüü-Szabó, B., Földesi, P., Kóczy T., L.: Az Utazó Ügynök Problémára alkalmazható diszkrét memetikus evolúciós metaheurisztikák összehasonlitása, LogisztikaInformatika-Menedzsment 2019, 4(1):15-30, https://doi.org/10.29177/LIM.2019.1.15 